\title{
Engaging Students in an Online Classroom Setting:
}

\author{
Reading and Retelling Short Story
}

\author{
Siti Mafulah*, Rizky Lutviana \\ English Education Department \\ Universitas PGRI Kanjuruhan Malang \\ Malang, Indonesia \\ *siti_mafulah@unikama.ac.id
}

\begin{abstract}
Online learning become a must thing to be applied in pandemic situation. This paper aimed to depict how students engage in the online class and how teacher gives the interesting way to tight the students' engagement. This study was done in Extensive Reading class. Thirty students were involved in this study. The Moodle online platform were applied. Observation was done to know how teacher and students' interaction and how students engage in the online classroom setting. Interview was done to know how the teacher's way in making class more interesting and enjoyable. The result showed that teacher always gave positive feedback to the student when they rewrote the story, sometimes feedback was given in the form of jokes. Teacher also shared motivational video to rise the students' motivation. To check students' competence, they were asked to make a video using their creativity and upload it on YouTube channel. All the effort done by the teacher makes the students engage well in the online classroom settings. Creative way can create new motivation and new spirit in learning.
\end{abstract}

Keywords—online learning, extensive reading, retelling story, student engagement

\section{INTRODUCTION}

Student engagement is an important thing to be considered by all teachers. Without engagement from the students in teaching learning process, the material will not be comprehended well. Student engagement can be defined as student commitment and activeness to the course [1]. Usually Engagement is categorized as students' positive behaviors and their sense of belonging in the classroom [2]. Without active participation from the students the class the class cannot be considered as success class. Therefore, teacher should raise student engagement to make effectiveness of the teaching learning process and make it succeed. Since the importance of student engagement in language learning, teacher should find way to promote it [3]. One way to promote it is using YouTube. YouTube is really closed to students, so that teacher can be utilized in teaching learning process. Moreover, in this pandemic situation YouTube becomes one of the useful tools to get information, to share teaching material and to post students' work. Besides, almost all universities are equipped with the learning management system.
Extensive reading or reading for pleasure is an enhancement of vocabulary for both first language and second language learners. It involves student's free selection of reading text and enjoy the reading. Moreover, extensive reading can be categorized into reading for general understanding and focus on meaning and manifested to general reading ability [4] and an approach to develop reading skills [5]. The difficulties of the text can be suited by the student's proficiency level. In Extensive Reading, students are allowed to choose a wide range of reading text, while they feel that the reading text is too difficult for them, they can put it down and find another one that they settle on understanding it [6]. To engage student in Extensive Reading, YouTube channel can be very useful to assess the students' comprehension in reading text. Reading comprehension is a process of extracting and constructing meaning through interaction and involvement with written text. Consequently, to assess the individual comprehension should consider the word recognition, fluency and vocabulary [7]. Students' reading comprehension can be assessed though oral retelling of previously text that is read by the student [8]. Moreover, oral retelling needs transformation of a written text in a written form into their own words. Although assessment is not one of the key features of extensive reading, however, teacher should know how far the students understand with the text that they have read.

Some previous studies have explored about Extensive Reading program. Rogiers et al. [9] investigated the relationship between reading enjoyment and reading comprehension among gender, socio-economic status (SES), and language background. The findings show positive relationship between reading enjoyment and reading comprehension. Furthermore, Girls who come from high socioeconomic status, and in the academic track get higher score in both reading enjoyment and reading comprehension. While those who are from vocational track get lower score in both reading enjoyment and reading comprehension. Additionally, L2 students got lower score in reading enjoyment and reading comprehension compared to the L1 students. Different to Rogiers et al., Lin [10] investigated the effect of technological tool (tablet PC and desktop PC) in an online Extensive reading program on English students' activities, reading ability, and users' perception. There were two groups, group one was 
assigned using tablet PCs and another group using desktop PCs. The findings show that students or group with tablet PCs outperformed better in online activities and reading achievement than group which use desktop PCs. Furthermore, the students who learn online using tablet PCs perceived better than the students who learn online using desktop PCs.

In addition, Stoller and Nguyen [11] focused on the English students' reading habits in Vietnam. The findings show that the students prefer to use digital material when they read for fun or relaxation $(61 \%)$ and for university studies, the students prefer to use printed materials $(60 \%)$. From the result of this study can be concluded that the students prefer to use each material based on their purposes whether it is for pleasure or for academic purposes. This study is not explored how the students show their comprehension after reading the text, so that it needs to explore how students comprehend and perceive the materials. Further analysis was done by Prasetyawati and Priyatno [3]. They investigated how the implementation of social media (Instagram) in promoting student engagement in EFL writing. The findings show that Instagram allows students to be more active, provides new learning environment, provides greater reader, allows collaboration and interaction among students, and facilitates students to choose their own learning styles when they are in the writing process. The result of this study focused on writing skills. Since there limited empirical studies concerning student engagement in extensive reading and reading comprehension, it is a need to conduct the study on this field. Therefore, this study is aimed to explore how students engage in an online classroom setting in extensive reading especially reading and retelling short story. Besides, to explore how teacher gives the interesting way to tight the students' engagement.

\section{METHODS}

The participant of this study involved 30 English major students who joined Extensive Reading Course and one teacher in Universitas PGRI Kanjuruhan Malang, Indonesia. This study used qualitative research using observation and interview as instruments. Observation was used to know the student engagement in the online classroom on extensive reading course especially in reading short story and retelling it. The observation was done in the online classroom setting provided by Spada Universitas PGRI Kanjuruhan Malang (spada.unikama.ac.id) and YouTube channel (Extensive Reading 2020). Moreover, interview was used to know the students' detail confirmation about the use of online setting and YouTube channel as the place to submit their oral report summary after reading short story. Besides, the interview was also delivered to the teacher to know how she manages Extensive Reading course to engage their students in the teaching learning process.

The data were the result of observation in an online Extensive Reading course, the result of observation in YouTube channel, and result of interview. The steps in collecting data were based on the following: first, the students were asked to read sort story based on their preference. The short story can be from the printed or digital sources. Second, students should comprehend the story and the last to measure the students' comprehension they have to retell the story orally and posted it on YouTube channel. the YouTube channel was managed by the class leader. Consequently, students who were late in submitting their oral report would not be uploaded by the class leader. After the students uploaded their oral report on YouTube, other students were expected to give comment for all friends' video. The comment can be in form of the content of the story, can be the form of the video or can be in the form of video maker.

The observation checklist was classified into several categories as mentioned in the table 1 .

TABLE I. OBSERVATION CHECKLIST GUIDE

\begin{tabular}{|c|c|c|c|}
\hline \multirow[t]{2}{*}{ No } & \multirow{2}{*}{$\begin{array}{c}\text { Online } \\
\text { learning } \\
\text { platform }\end{array}$} & \multicolumn{2}{|r|}{ Observed Thing } \\
\hline & & Categories & Indicator \\
\hline 1 & $\begin{array}{l}\text { Spada } \\
\text { Unikama }\end{array}$ & $\begin{array}{l}\text { Active } \\
\text { engagement }\end{array}$ & $\begin{array}{l}\text { 1. } \begin{array}{l}\text { Participating in online } \\
\text { discussion about the } \\
\text { assignment. }\end{array} \\
\text { 2. } \begin{array}{l}\text { Asking/questioning the } \\
\text { teacher about the } \\
\text { assignment. }\end{array} \\
\text { 3. } \begin{array}{l}\text { Giving reaction /answering } \\
\text { teacher's question. }\end{array} \\
\text { 4. } \begin{array}{l}\text { Giving suggestion /opinion } \\
\text { to others. }\end{array} \\
\text { 5. Submitting the assignment } \\
\text { on time. }\end{array}$ \\
\hline & & $\begin{array}{l}\text { Passive } \\
\text { engagement }\end{array}$ & 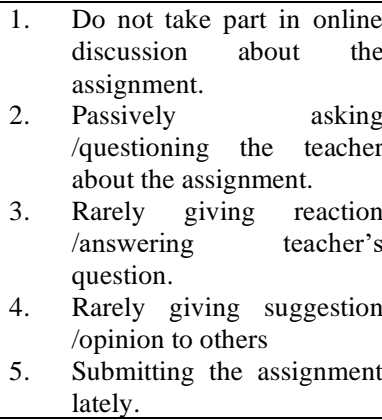 \\
\hline 2 & YouTube & $\begin{array}{l}\text { Active } \\
\text { engagement }\end{array}$ & $\begin{array}{l}\text { 1. Submit the video on time. } \\
\text { 2. Giving comment on } \\
\text { friends' video. } \\
\text { 3. Responding on friends' } \\
\text { comment. } \\
\text { 4. Receive the suggestion to } \\
\text { make their next video better }\end{array}$ \\
\hline & & $\begin{array}{l}\text { Passive } \\
\text { engagement }\end{array}$ & $\begin{array}{l}\text { 1. Submit the video lately } \\
\text { 2. Rarely give comment on } \\
\text { friends' video. } \\
\text { 3. Do not give respond on } \\
\text { friends' comment } \\
\text { 4. Do not receive the } \\
\text { suggestion to make their } \\
\text { next video better. }\end{array}$ \\
\hline
\end{tabular}

From table 1, it can be seen that active engagement is the students actively attending to the assigned task. It is indicating by participating in online discussion about the assignment, asking or questioning the teacher about the assignment, giving 
reaction or answering teacher's question, giving suggestion /opinion to others, and submitting the assignment on time. While for passive engagement is the contradiction of the active one. For the engagement in YouTube channel, it is indicated by Submit the video on time, giving comment on friends' video, responding on friends' comment, and receive the suggestion to make their next video better.

After collecting the data, the data will be analyzed and served in the form of narration or description.

\section{RESULtS}

Based on the interview result, to engage students in Extensive Reading course, the teacher always gave positive feedback to the student when they rewrote the story, sometimes feedback was given in the form of jokes. This form of feedback is to reduce the students' stress in facing their online class. Teacher's statement of the feedback: "Negative feedback will demotivate the students". Teacher also shared motivational video to rise the students' motivation. The video was uploaded on Spada Unikama before the Extensive Reading course schedule so that students can watch the video, the video can be assessed whenever the students want to. This was done to motivate students in reading as much as possible so that reading habit can be set as one of goals of this course.

Result of the observation showed that most of the students engage positively in joining Extensive Reading through Spada Unikama. It can be seen from the number of students who participate in online discussion (28 students), meaning that 93\% students are active participating in the discussion. 26 students or $86 \%$ from the total number of students were actively questioning the teacher about the assignment. All students answered or gave reaction to the teacher's question while number of students who gave reaction to their peer were 20 students or $67 \%$ from the total number of students (see Table 2).

TABLE II. STUDENT'S ENGAGEMENT WITH SPADA UNIKAMA

\begin{tabular}{|c|c|c|c|c|}
\hline No & Indicators & $\begin{array}{c}\text { Active } \\
\text { (number } \\
\text { of student) }\end{array}$ & $\begin{array}{c}\text { Passive } \\
\text { (number of } \\
\text { student) } \\
\end{array}$ & Total \\
\hline 1 & $\begin{array}{l}\text { Participating in online } \\
\text { discussion about the } \\
\text { assignment. }\end{array}$ & $28(93 \%)$ & $2(7 \%)$ & $30(100 \%)$ \\
\hline 2 & $\begin{array}{l}\text { Asking/questioning } \\
\text { the teacher about the } \\
\text { assignment. }\end{array}$ & $26(86 \%)$ & $4(14 \%)$ & $30(100 \%)$ \\
\hline 3 & $\begin{array}{ll}\text { Giving } & \text { reaction } \\
\text { /answering } & \text { teacher's } \\
\text { question. } & \end{array}$ & $30(100 \%)$ & $0(0 \%)$ & $30(100 \%)$ \\
\hline 4 & $\begin{array}{l}\text { Giving suggestion } \\
\text { /opinion to others. }\end{array}$ & $20(67 \%)$ & $10(33 \%)$ & $30(100 \%)$ \\
\hline 5 & $\begin{array}{l}\text { Submitting the } \\
\text { assignment on time. }\end{array}$ & $27(90 \%)$ & $3(10 \%)$ & $30(100 \%)$ \\
\hline
\end{tabular}

Twenty students were actively giving suggestion or opinion to their friends, it means that more than $50 \%$ from the total number of students were active in the online classroom setting.
The result of the student engagement with Extensive Reading through YouTube can be seen on table 3.

TABLE III. STUDENT's ENGAGEMENT WITH YoUTUBE

\begin{tabular}{|c|l|c|c|c|}
\hline No & \multicolumn{1}{|c|}{ Indicators } & $\begin{array}{c}\text { Active } \\
\text { (number } \\
\text { of student) }\end{array}$ & $\begin{array}{c}\text { Passive } \\
\text { (number } \\
\text { of student) }\end{array}$ & Total \\
\hline 1 & $\begin{array}{l}\text { Submit the video on } \\
\text { time }\end{array}$ & $5(17 \%)$ & $25(84 \%)$ & $30(100 \%)$ \\
\hline 2 & $\begin{array}{l}\text { Give comment on } \\
\text { friends' video }\end{array}$ & $21(70 \%)$ & $9(30 \%)$ & $30(100 \%)$ \\
\hline 3 & $\begin{array}{l}\text { Give respond on } \\
\text { friends' comment }\end{array}$ & $19(63 \%)$ & $11(37 \%)$ & $30(100 \%)$ \\
\hline 4 & $\begin{array}{l}\text { Receive the suggestion } \\
\text { to make their next } \\
\text { video better. }\end{array}$ & $20(67 \%)$ & $10(33 \%)$ & $30(100 \%)$ \\
\hline
\end{tabular}

From the table 3 can be seen that most indicators show the active engagement of the students. 21 students or $70 \%$ from the total number of students involved in giving comment on their friends' video. More than half number of students give their responses to their friends' comment. It can be concluded that the engagement of the students with retelling the story and uploading on YouTube for time submission was really passive, while for the other indicators show the students engage positively.

\section{DISCUSSION}

The engagement of the students in reading and retelling the story found that the students engage actively in accordance with using Spada Unikama as the online classroom setting. Similarly, the use of YouTube is also engage the students actively except in the time submission. Active engagement through online classroom setting provides new learning environment, provides greater reader, allows collaboration and interaction among students [3]. The exception of the activeness of the students is in submitting the assignment. One of the students told the teacher the reason why she cannot submit the assignment on time, it is because of the memory of her mobile phone. After making a video suddenly the video cannot be saved because of full memory. Other students also gave their reason that there were difficulties in uploading the video to YouTube channel. First, the YouTube admin was the class leader so that the video should be uploaded in a queue. Second, the regulation from YouTube that in one day, one YouTube account only can upload maximum 5 videos. Therefore, the difficulties in submitting on time cannot be avoided.

Although the difficulties faced by the students in uploading their video on YouTube makes the engagement seems passively, this situation is different to the result of interview. The result of interview shows that the students were happy with the assignment because they can express what they have read.

"I'm really happy with this assignment, ma'am. I can express my competence in retelling the story and editing the video" (student 2) 
"many new words that I never know before, I can improve my vocabulary when read new story and find the meaning on dictionary" (student 5)

This finding point is similar to Ro [12] that argues that the reason of the students like Extensive Reading are the intrinsic value such as reading for pleasure, fun, and can be done wherever and whenever they want. The freedom of choosing the topic or book is also one of reason why students like reading. In term of giving comment and responding to their friends' comments. There was good interaction among the students. Online classroom setting made students feel free to discuss with their friends rather than with their teacher $[13,14]$. Some of the categories in giving respond to the other students' video was found in this research. First, appreciating their friends' work such as "it is good job dear" "it's great", "I love the way you retell"'

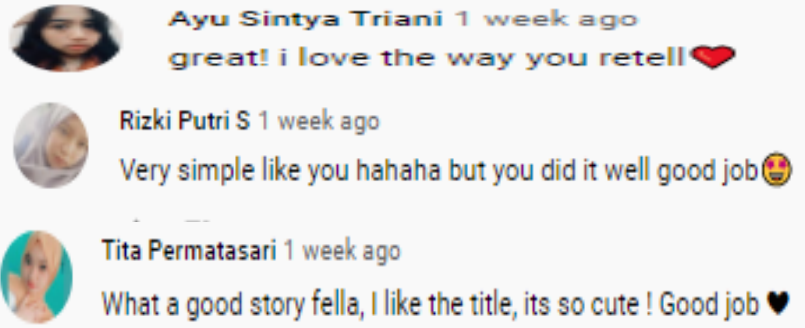

Fig. 1. Students'appreciation.

Second, the students show their surprise because they never their friends' confidence in speaking. They never show their confidence in face-to-face class and he never show off their capability in offline class. While in his video he looks so condidence with his skill in retelling the story. The example of showing surprise can be seen on figure 2 .

(2).

Tari- Sri Lestari 1 week ago

This is the first time I see your confidence. Good job, Mate. Keep being awesome.

14 1 II REPLY

Tita Permatasari 1 week ago

Your voice is clear yudha, so I can understand the story very well, good job !

1) 1 REPLY

Fig. 2. Students' surprise utterances.

Third, the students' renponses of their friends' video as critics to make the video better. " it is better for you to can add the volume of the audio of your video" this utterance was written on comment coloumn to remind her friends when their friends'voice cannot be heard clearly. In addition, there was a student who gave suggestion in making the video such as the lighting setting. "you can add a ligthing when you take video so anyone can see your beautiful face".
Rizki Putri 1 bulan lalu

You edited the video very well devi, but maybe in the next video you can add a lighting when you take your video so everyone can see your beautiful face but you did it well good job (응

Fig. 3. Advice or suggestion to make the quality of video better

The example of students' responses on friends' comment can be seen in figure 4. After getting comment from their friends, whether it is good comment or not, student whose video uploaded and given comment should respond to the comment.

(E) Rizki Putri S 1 bulan lail

Your voice and your pronunciation is very clear so i can understand it well good job sasa 1) BALAS

- Sembunyikan balasan

Zasha Andika 4 minggu lalu Thank youuuu Putriiii :

nanda gita 1 bulan lalu

Your pronunciation is pretty good, keep it up Sasa

It g1 BALAS

- Sembunyikan balasan

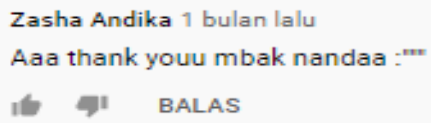

Fig. 4. Students' interaction on YouTube comment column

Active engagement make the teaching learning process runs well [15]. The students can explore what they have to retell. They also can deliver the story based on their own sentences. Extensive reading promotes students reading ability [4]. Furthermore, Yamashita suggests that extensive reading contribute to the acquisition of vocabulary and/or expressions rather than to the ability to read and comprehend a coherent written text.

This results of the study also confirm that students preferred to read on digital text when they do extensive reading or reading for fun [11]. It cannot be refuted that most of the students in Extensive Reading course found the short stories from many sources in digital text form. The use of mobile assisted learning is useful for students to engage actively in online learning process [10]. To tight the student engagement, teacher can use creative way in teaching process. All the effort done by the teacher makes the students engage well in the online classroom settings. Creative way can create new motivation and new spirit in learning. Besides, mobile assisted learning and computer assisted learning open new path to the students to go beyond their competence in facing new era [16]

\section{CONCLUSION}

The effectiveness of teaching learning process cannot be separated from student engagement. Therefore, teacher should 
engage the students with creative and innovative way in teaching. Moreover, in this pandemic situation which requires teacher to utilize technology in the teaching learning process. Active engagement is not only affected by the teacher's role but also the external caution such as the regulation of the tool and the devices, the capacity of memory can also affect the student engagement. The engagement of the students can be concluded that students are active in Extensive Reading course through technological platform and application such as Spada Unikama and YouTube

This study explores limited subject of the participant, it is only applied in one class of Extensive Reading course. This study is not determined the difference of the gender on the exploration of student engagement. For further research, researchers can explore a wide range of number of participants across gender or with other English skill courses.

\section{REFERENCES}

[1] Y. Han and F. Hyland, "Exploring learner engagement with written corrective feedback in a Chinese tertiary EFL classroom," J. Second Lang. Writ., vol. 30, pp. 31-44, 2015.

[2] Z. (Victor) Zhang and K. Hyland, "Student engagement with teacher and automated feedback on L2 writing," Assess. Writ., vol. 36, no. February, pp. 90-102, 2018.

[3] O.A. Prasetyawati and A. Priyatno, "Integrating Instagram Into Efl Writing To Foster Student Engagement," vol. 20, no. July, pp. 40-62, 2020.

[4] J. Yamashita, "Extensive reading and development of different aspects of L2 proficiency," System, vol. 36, no. 4, pp. 661-672, 2008.

[5] S. McLean and G. Rouault, "The effectiveness and efficiency of extensive reading at developing reading rates," System, vol. 70, pp. 92 106, 2017.
[6] S. Krashen and B. Mason, "Sustained Silent Reading in Foreign Language Education: An Update," Turkish Online J. English Lang. Teach., vol. 2, no. 2, pp. 70-73, 2017.

[7] I. Ribeiro, I. Cadime, T. Freitas, and F.L. Viana, "Beyond word recognition, fluency, and vocabulary: The influence of reasoning on reading comprehension," Aust. J. Psychol., vol. 68, no. 2, pp. 107-115, 2016.

[8] M. Kocaarslan, "The effects of reading rate, accuracy and prosody on second grade students," Acta Psychol. (Amst)., vol. 197, no. September 2018, pp. 86-93, 2019.

[9] A. Rogiers, H. Van Keer, and E. Merchie, "The profile of the skilled reader: An investigation into the role of reading enjoyment and student characteristics,” Int. J. Educ. Res., vol. 99, no. October 2018, 2020.

[10] C.C. Lin, "Learning English reading in a mobile-assisted extensive reading program," Comput. Educ., vol. 78, pp. 48-59, 2014.

[11] F.L. Stoller and L.T.H. Nguyen, "Reading habits of Vietnamese University English majors," J. English Acad. Purp., vol. 48, p. 100906, 2020.

[12] E. Ro, "Exploring teachers' practices and students' perceptions of the extensive reading approach in EAP reading classes," J. English Acad. Purp., vol. 22, pp. 32-41, 2016.

[13] B. Xu, N.S. Chen, and G. Chen, "Effects of teacher role on student engagement in WeChat-Based online discussion learning," Comput. Educ., vol. 157, p. 103956, 2020.

[14] M. Alghasab, J. Hardman, and Z. Handley, "Teacher-student interaction on wikis: Fostering collaborative learning and writing," Learn. Cult. Soc. Interact., vol. 21, no. December 2018, pp. 10-20, 2019.

[15] C.C. Wolverton, "Utilizing synchronous discussions to create an engaged classroom in online executive education," Int. J. Manag. Educ., vol. 16, no. 2, pp. 239-244, 2018.

[16] Y.F. Yang and N.C. Kuo, "New teaching strategies from student teachers' pedagogical conceptual change in CALL," System, vol. 90, p. $102218,2020$. 